Volume 11

\title{
Film Review: Concerning Violence - Nine Scenes From the Anti- imperialistic Self-Defense (2014)
}

Piotr Cieplak

Brunel University London

Follow this and additional works at: https://digitalcommons.usf.edu/gsp

\section{Recommended Citation}

Cieplak, Piotr (2017) "Film Review: Concerning Violence - Nine Scenes From the Anti-imperialistic SelfDefense (2014)," Genocide Studies and Prevention: An International Journal: Vol. 11: Iss. 1: 126-128. DOI:

http://doi.org/10.5038/1911-9933.11.1.1489

Available at: https://digitalcommons.usf.edu/gsp/vol11/iss1/18

This Film Review is brought to you for free and open access by the Open Access Journals at Digital Commons @ University of South Florida. It has been accepted for inclusion in Genocide Studies and Prevention: An International Journal by an authorized editor of Digital Commons @ University of South Florida. For more information, please contact digitalcommons@usf.edu. 


\title{
Film Review: Concerning Violence - Nine Scenes From the Anti-Imperialistic Self-Defense
}

\author{
Piotr Cieplak \\ Brunel University London \\ London, United Kingdom
}

Concerning Violence - Nine Scenes From the Anti-Imperialistic Self-Defense

Director: Göran Olsson

Sweden, Finland, Denmark, USA, 2014

Reviewed by Piotr Cieplak

Brunel University London

Göran Olsson's Concerning Violence - Nine Scenes From the Anti-Imperialistic Self-Defense (2014) is an unusual documentary, which - formally and thematically-probes the complex relationship between image, voice and histories. It is Olsson's second film. The first, The Black Power Mixtape 1967-1975 (2011), used footage shot by Swedish journalists in the 1960s and 1970s to explore the Black Power Movement in the United States. Very much like its predecessor, Concerning Violence also relies on images not originally shot by Olsson. Dug out from Swedish archives, the footage of the liberation struggles in Angola, Mozambique, Guinea-Bissau, (former) Rhodesia, accompanied by other scenes of colonial and early post-colonial life, oppression and exploitation across Africa, sets out to illustrate and, in the more brilliant moments of the film, converse with extracts from Franz Fanon's The Wretched of the Earth (1961). ${ }^{1}$

Fanon's well-known treatise (banned in France and the U.S. soon after publication) painfully and painstakingly itemizes and deconstructs the different forms of violence and oppression that lie at the very heart of the colonial project. It also contemplates the tragedy of violence being the only available response to colonization. The merits and shortcoming of Fanon's text have been amply discussed and are of no particular relevance here. It is worth mentioning, however, that the first edition of The Wretched of the Earth carried an introduction by Jean-Paul Sartre.

Unusually, some would say perilously, for a film, Concerning Violence also seeks a philosophical, academic endorsement at its very beginning. The documentary starts with a 6-minute lecture-like introduction (shot very simply and consisting of only four shots) by Gayatri Chakravorty Spivak. Sat in her Princeton University office, surrounded by shelves and piles of books, journals and manuscripts, Spivak introduces Fanon and the film. She also mentions Sartre's preface to the original text and admonishes the philosopher for reading the book as "an endorsement of violence itself" rather than a contemplation of the impossible position of the colonized who is reduced to violence as the only viable response to the colonial project. $^{2}$

One of the most basic and important principles of filmmaking is show not tell. An introduction that summarizes the film (Spivak at one point actually says: "Here now is our film") is a bold and potentially disastrous move. But it does pay off for Olsson. The archive used in the film can feel labyrinthine. It covers diverse geographical, political, cultural and economic locales; often with limited guidance and restricted context. This introductory section helps to orientate the viewer; provides a useful starting point. The section is didactic but does not feel heavy-handed. Spivak does not simply provide the historical and theoretical background. She also challenges Fanon and speaks about the often overlooked gendering of both colonial oppression and liberation struggle, about how revolutionary activity can emancipate women and then return to their subjugation. She singles out the shot of a Mozambican woman whose arm has been amputated as a result of Portuguese bombings (Spivak calls her "the black venus") as the most moving image of the film.

After this introductory section, Concerning Violence is visually comprised exclusively of the archive material captured by Swedish journalists. The first image shows a black man shining a shoe

\footnotetext{
${ }^{1}$ The film takes its title from one of the essays in The Wretched of the Earth.

${ }^{2}$ This criticism of Sartre's interpretation has also been put forward by other scholars, including Homi Bhabha.
} 
worn by a white foot - the theme of racial, cultural and economic oppression is set out clearly from the beginning and comes back many times in the film. It is followed by another mini-section in which we see white soldiers in a helicopter, shooting at cattle in an open field. The animals are helpless; there is nowhere to hide. The technological advantage of the weaponry of war and the distance from which it can be used are completely overwhelming. We then move on to a close ups of the head of one of the cows being shot at point blank. Blood streams from the nostrils and the mouth. ${ }^{3}$

The juxtaposition and metaphor are, perhaps, a little obvious in these opening images. But their presence and execution are telling of the peculiar formal nature of Concerning Violence. Working exclusively with the archive, Olsson does not have all the tools usually available to a director. He cannot decide where to point the camera, what to film, what angle to employ. The images at his disposal have not only been shot by someone else (and in fact have multiple authors) but are also from a particular era. Here, the process of re-contextualization of the archive inevitably depends on editing (shot selection, chronology, structure, duration, pace, rhythm, juxtaposition, contrast) and on the audio track that accompanies the images. These directorial interventions, as much as the archive itself (so aesthetically seductive and so firmly placed in the past), shape the narrative and give meaning to the footage - meaning that is a mixture of the footage's original designation and its re-contextualized existence.

The film is divided into nine sections or chapters. Some retain their original audio (including interviews and pieces of narration). Others are accompanied by an eerie soundtrack composed especially for Concerning Violence, occasionally reminiscent of the soundscape of another seminal compilation documentary: Emile de Antonio's In the Year of the Pig (1968). But by far the most striking sound in the film are the extracts from The Wretched of the Earth read by the American rapper, singer and songwriter Ms. Lauryn Hill. Hill's voice is authoritative, melodic, beautiful. It combines conviction, pent-up anger and, towards the end of the film, sounds like a call to action rather than mere commentary. The extracts from Fanon, although short, are carefully chosen and, most of the time, land very effectively on the archival footage. As well as being spoken by Hill, the passages appear in writing on screen.

The potential connection between Fanon's words and the archival footage in Concerning Violence is one of the most fascinating aspects of the film. On the one hand, the words shape the footage. They provide it with context (in the sense of the images being able to be placed within and used as illustrations of the wider trends of colonial oppression and anti-colonial struggle across the continent, as seen by Fanon). They also help to carry the structure of the film in that the choice of passages (and the accompanying images) dissects and zooms in on particular aspects of the colonial project and the reaction to it. On the other hand, this kind of contextualization inevitably remains quite general. Even though places, people, particular liberation movements are often named, there is a very strong sense that these unique images are illustrative rather that dialogical, discursive vis-à-vis the text.

This could be seen as a mark of passivity of the images in relation to a seminal text that is imposed on them (Fanon, after all, was not writing specifically about the places or events shown in the film). However, Olsson manages to let the footage breathe in its own right, as well as creating the feeling that it is part of a bigger whole, a bigger process. Within the generalized discourse of colonial violence and anti-colonial struggle, Olsson is able to create moments of intimacy and particularity (some of them very uncomfortable). These moments are ample in the film. To mention just a few: an interview with a racist white settler (in section three, entitled "Rhodesia") who admonishes his servant for not opening a beer bottle, bemoans the situation in the country and concludes that "The gooks have got it"; the plight of the family of Robert Jackson (an employee of Lamco - a Swedish/American mining company in Liberia) who are evicted from their house for Jackson's participation in a strike and left homeless and destitute on the side of the road, in the middle of the night (in section five, entitled "Lamco-Liberia, 1966"); the lingering shot of the woman with her arm amputated, breastfeeding a baby who lost a let in the same attack by the Portuguese (in section eight, entitled "The Fiat G.91, with the FRELIMO in Mozambique 1972").

\footnotetext{
${ }^{3}$ This image is reminiscent of the slaughtered cow in Sergei Eisenstein's Strike (1925)
} 
Even though many of the protagonists of these images remain unnamed and, arguably, illustrative, the potentially abstract and general points about the complexity of co-habitation of the colonized and the colonizers, about the economic face of colonial and post-colonial violence, about the sacrifices of the anti-imperial struggle become somehow more urgent, more real as a result of the editorial choices made by Olsson.

This sense of urgency is another important marker of Concerning Violence. There is a risk in making a film so firmly based in the past-consisting entirely of archival footage and structured with the help of a text published in the 1960s. This risk is datedness. One of Olsson's biggest achievements is the fact that Concerning Violence feels so pertinent. It is not a helpless, purely illustrative film. Towards the end, the tone and content of the narration turn towards action. Hill, in Fanon's words, warns Africa not to try to emulate Europe but to choose a different path. The U.S. is invoked as an example of a former colony that followed the example of the colonizer and became an oppressor of others itself. In a similar vein, the latter parts of the film suggest the longevity of economic oppression that was born under colonialism (one of the original engines of capitalism) and continues to thrive (often challenged but rarely defeated) long after independence was achieved. While firmly set in the past the film succeeds in being an urgent comment on the present.

Concerning Violence demands effort from the viewer. The unusual formal make up of the film and the jigsaw-like co-existence of the images, narration/text and concepts requires a very active viewing if it is not to fall into the realm of obscurity or abstraction. It is a viewing mode of a particular kind, a viewing that implicates. The presence of implication, the impossibility of neutrality, for me, lies at the heart of the film. It feels reductive to describe a good documentary as a useful didactic text-it seems to take away from its value as a work of art rather than pure document. But such description does not seem pejorative in the case of Concerning Violence-at once a highly subjective, poetic text and a useful point of engagement with Fanon and the legacy and colonialism more generally.

Title of the Film: Om våld (Concerning Violence - Nine Scenes From the Anti-Imperialistic Self-Defense); Director: Göran Olsson; Producers: Tobias Janson, Annika Rogell; Screenplay: Göran Olsson, Frantz Fanon (based on his book); Cinematography: Lis Asklund, Bo Bjelfvenstam, and others; Film Editors: Michael Aaglund, Dino Jonsäter, Göran Olsson, Sophie Vukovic; Sound Designer: Micke Nyström; Country: Sweden, Finland, Denmark, USA; Year of Release: 2014; Production Company: Final Cut for Real, Helsinki Filmi Oy, Louverture Films. Duration: 78 minutes. 